\title{
血液浄化膜の吸着性の検討
}

$\begin{array}{lllllllll}\text { 阿部町子 保科繁 } & \text { 池田 裕 } & \text { 中村 } & \text { 藤 夫 } & \text { 古川 守 } \\ \text { 遠 藤 信之 } \\ \text { 信楽園病院腎センター }\end{array}$

(昭和 61 年 9 月 1 日受付)

key words : adsorption, $\beta_{2}-\mathrm{MG}$, PMMA, PAN

〈要旨〉

我々は滤過型人工腎の治療において, 低分子蛋白質が膜による選択的吸着を受けることをすでに報告した。 今回 PMMA 膜 3 種類 (B1 系 high flux 型 HF-200, 蛋白透過型 BK-1.0 H, B2 系B2-1.3), PAN 膜 (PAN-140), cuprohan 膜 (MC-0.8) についての吸着実験を試み, 各種溶質についての経時的吸着性を検討した。

透析患者のプール血漿に各種膜の小切片を加えて, 室温下で 3 時間のインキュベーションを行った。 そして 30 分, $1 ， 2 ， 3$ 時間ごとに各種溶質の測定を行い, 実験前值を $100 \%$ とした時の各経時値を算出した.

B1 系 (HF-200, BK-1.0 H) と B2 系 (B2-1.3) では，同じ PMMA 膜であるが全く異なった吸着性を示した. B1 系の膜ではグルカゴン, N末端-PTH, $\beta_{2}$-ミクログロブリンが強度の低下を示し, B2 系の膜ではN末端-PTH, リゾチ ウムの低下が著明であった. PMMA 膜において, $\beta_{2}$-ミクログロブリンは強度の低下を示すとすでに報告したが, 弚 れはB1 系の膜においてであって, 今回試みた B2 系の膜では若干の低下を示しただけであった.PAN 膜におけるリ ゾチウム, リボヌクレアーゼの強度の低下は前回同様であった。 今回新たに検討したN末端-PTH は B1 系 PMMA 膜, PAN 膜のいずれでも低下が著明であった. Cuprohan 膜については各溶質とも有意な低下は認められなかった.

\section{Membrane-specific adsorption of uremic plasma solutes by the membranes for blood purification}

Machiko Abe, Sigeru Hoshina, Yutaka Ikeda, Fujio Nakamura, Mamoru Furukawa, Nobuyuki Endo, Ichiro Nakagawa, Hisao Urano, Masashi Suzuki, M. D., Yoshihei Hirasawa, M. D.

Kidney Center, Shinrakuen Hospital

$\beta_{2}$-microglobulin $\left(\beta_{2}-M G\right)$ was recently recognized as the new type amyloid protein in chronic dialysis patients. Significant reduction of plasma $\beta_{2}-M G$ without sieving effect in the hemofiltration using PMMA membrane suggested the specific adsorption of $\beta_{2}$-MG on PMMA membrane. Our examination revealed the verious and specific adsorption effects of PMMA (B-1 but not B-2), and PAN membrane. Cuprophan membrane showed no adsorption effects at all. The results suggest that some kinds of uremic plasma solutes as well as $\beta_{2}-\mathrm{MG}$ could be removed by membrane-specific adsorption mechanism.

\section{目的}

最近長期透析患者に扔いて，低分子のみならず中・高 分子量物質の蓄積が盛んに問題とされている。昨年，小 分子量蛋白である $\beta_{2}$-ミクログロブリン (以下 $\beta_{2}-\mathrm{MG}$ ) が透析性アミロイドーシスの原因物質と同定されるに至 $\eta^{1)}$, これをいかに効果的に除去するべきかが注目され てきている，そして血液透析法あるいは血液滤過法を行 うことにより，その中分子量物質を膜透過，膜吸着によ

阿部 町子 信楽園病院腎センター

广 950-21 新潟市西有明町 1-27 (025-267-1251)
り除去可能な high-flux 型 dialyzer の開発もなされて きた ${ }^{2}$.しかしまたその膜吸着の様態は, 溶質, 膜により かなり異なった選択的なものであることも実証されてい る3).

そこで今回我々はその膜吸着について, PMMA 膜 3 種類, PAN 膜, cuprohan 膜を用いて以下の吸着実験を 試みた。そして各種溶質の経時的吸着性を検討した。

\section{方法}

まず多数の慢性透析患者の血漿を集めてプールした。 また PMMA 膜 3 種類 (B1 系 high-flux 型 HF-200, 蛋 
表 1 各種膜仕様

\begin{tabular}{|c|c|c|c|c|c|c|}
\hline & \multicolumn{3}{|c|}{ Material } & $\begin{array}{c}\text { Surface } \\
\text { area }\end{array}$ & $\begin{array}{c}\text { Inside } \\
\text { diameter }\end{array}$ & $\begin{array}{c}\text { Wall } \\
\text { thickness }\end{array}$ \\
\hline $\mathrm{HF}-200$ & \multirow{3}{*}{ PMMA } & \multirow{2}{*}{$\begin{array}{l}\text { B-1 } \\
\text { type }\end{array}$} & High flux & 2.01 & 245 & 33 \\
\hline $\mathrm{BK}-1.0 \mathrm{H}$ & & & 蛋白透過膜 & 1.01 & 245 & 32.5 \\
\hline B2-1.3 & & \multicolumn{2}{|c|}{ B-2 type } & 1.33 & 270 & 20 \\
\hline PAN-140 & \multicolumn{3}{|c|}{ PAN } & 1.4 & 200 & 55 \\
\hline MC- 0.8 & \multicolumn{3}{|c|}{ Cuprophan } & 0.8 & 200 & 7 \\
\hline
\end{tabular}

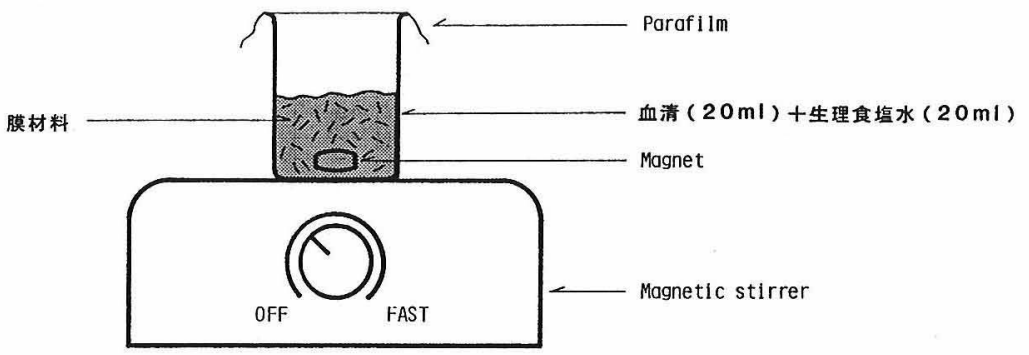

図 1 吸着実験図

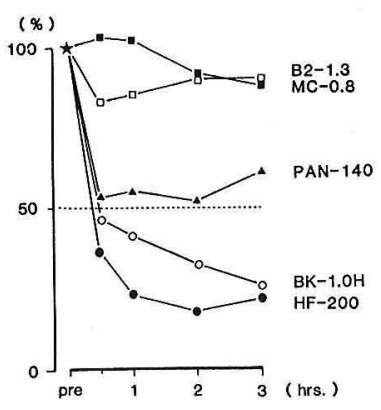

a : Glucagon

(MW:3500) $n: 5$

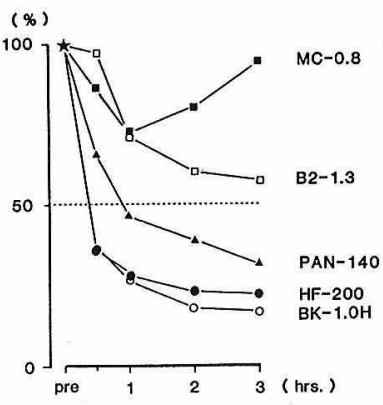

b : PTH-INS

(MW:9500) n : 5

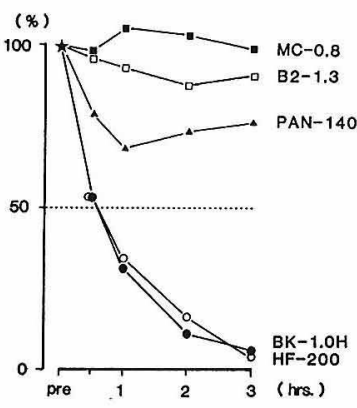

c : $\beta_{2}$-microgloburin (MW:11800) $n: 5$

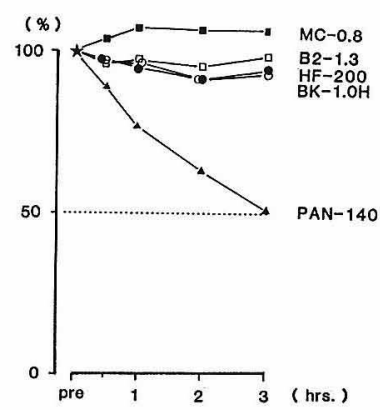

d : Ribonuclease (MW:14000) n : 5

図 2 各種膜における溶質の経時的変化(1)

白透過型 $\mathrm{BK}-1.0 \mathrm{H}, \mathrm{B} 2$ 系B2-1.3), PAN 膜 (PAN140), cuprohan 膜 (MC-0.8) を, 約 $5 \mathrm{~mm}$ 程度に細切 したものを用意した。なお以上用意した膜の仕様は表 1 に示した.

プール血漿から析出したフィブリンをガーゼで除去 し，この $20 \mathrm{~m} l$ に生理食塩水 $20 \mathrm{~m} l$ を加えて 2 倍に希釈 しビーカーに移した。これにそれぞれの膜材料の細切片 を $1.2 \mathrm{~g}$ を加え，ビーカーをパラフィルムでカパーした。 これをマグネットスターラーを用い室温で 3 時間のイン
キュベーションを行った。そして 30 分後， 1，2，3 時 間ごとに各種溶質の測定を行った。以上の実験を同一膜 材料につき, 各々 5 回繰り返し行った(図 1 ).なお測定 項目はグルカゴン， C末端・N末端の PTH, $\beta_{2}-\mathrm{MG}$, リ ボヌクレアーゼ, リゾチウム, ミオグロビン, レチノー ル結合蛋白， $\alpha_{1}$-ミクログロブリン，トランスフェリン， 以上 10 項目とした。そして各検査項目につき, 実験前值 を100\%とした時の各経時值を算出した。 


\section{結果}

1.グルカゴン（図 2-a )

HF-200・BK-1.0 H では，30 分後 50\%，3 時間後に は30\%以下まで低下していた。 B2-1.3 と MC-0.8では, 3 時間後でも $90 \%$ 前後という若干の低下であった. PAN-140 では，30 分後 60\%以下まで低下したが，その 後の低下は認められなかった。

2. N末端-PTH (図 2-b)

HF-200, BK-1.0 H では 30 分後 40\%，3 時間後には 20\%近くまで低下していた。 B2-1.3 と PAN-140では 3 時間後 B2-1.3 で 57\%, PAN-140 で31\%まで低下して いた。MC- 0.8 では 3 時間経過後でも $94 \%$ と微量の低下 であった。

\section{3. $\beta_{2}-\mathrm{MG}$ (図 2-c)}

HF-200, BK-1.0 H では 3 時間後には $6 \%$ 以下という 強い低下を示した。しかし B2-1.3 においては，91\%と いう若干の低下であった。PAN-140 では 1 時間後には 70\%まで低下したが, その後の低下は認められなかった。 MC-0.8 では 3 時間経過後も全く低下は認められなかっ た。

\section{4.リボヌクレアーゼ (図 $2-\mathrm{d})$}

PAN-140での低下が最も特徵的であり，3 時間後に は $51 \%$ という結果であった。 PMMA 膜 3 種類では， 3 時間経過後微量の低下を示し, MC-0.8では, 全く低下は 認められなかった。

5。リゾチウム (図 3-a)

前のリボヌクレアーゼ同様, PAN-140での低下が特 徵的で, 著しく強く 30 分後には $9 \%$ まで低下していた。 PMMA 膜 3 種類では， 3 時間後 44 57\%という結果で あった。MC- 0.8 では 3 時間経過後でも $94 \%$ という微量 の低下であった。

6.ミオグロビン（図 3-b)
PAN-140 では 3 時間後 89\%, PMMA 膜 3 種類では 69〜 85\%という結果であった. MC-0.8 では 3 時間経過 後も全く低下は認められなかった。

7.レチノール結合蛋白 (図 3-c)

HF-200, BK-1.0 H において, 他の膜に比べ有意な低 下を示し， 3 時間後 $66 \%$ 以下という結果であった. しか し B2-1.3 では 97\%という微量の低下であった. PAN140,MC-0.8では，3 時間経過後も全く低下は認められ なかった。

8. $\alpha_{1}-\mathrm{MG}$ (図 3-d)

HF-200, BK-1.0 H では 3 時間後 $82 \%$ 以下まで低下し ていた。 その他の膜においては, ほとんど低下らしい数 値は得られなかった。

またC 末端-PTH, トランスフェリンについては, 今回 使用したいずれの膜においても有意な低下は得られな かった.

さらに以上の結果を, 膜別に 3 時間後の各種溶質レベ ルを図 4 , 図 5 に示した。

PMMA 膜については図 4 の如く, B1 系 HF-200, BK-1.0 H と, B2 系 B2-1.3 とでは同じ PMMA 膜であ るがまったく異なった数值レべルを示した. B1 系の膜で は,グルカゴン, $\mathrm{N}$ 末端-PTH, $\beta_{2}-\mathrm{MG}$ が強度の低下を 示し, $\mathrm{B} 2$ 系の膜では, $\mathrm{N}$ 末端-PTH, リゾチウムの低下 が著明であった。

PAN 膜については, リゾチウムの強度の低下と, N末 端-PTH, リボヌクレアーゼの低下が著明であった。 $\mathrm{Cu}$ prohan 膜については, 各溶質とも有意な低下は認められ なかった。

\section{考察}

尿毒症に対する血液浄化療法の 1 つに血液濾過法（以 下 HF) がある.HF とは hemofilter による限外濾過に て物質を除去する療法であり, 我々はこれまでも各種の

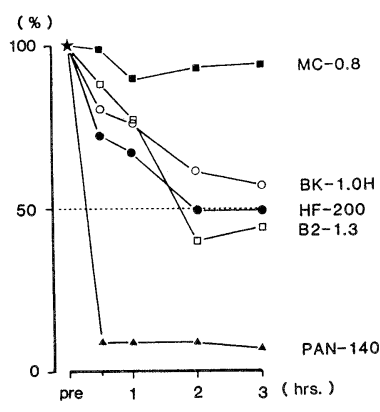

a : Lysozyme (MW:14600) $n: 5$

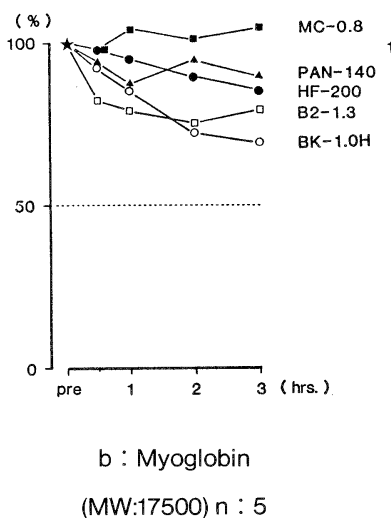

(MW:17500) n : 5

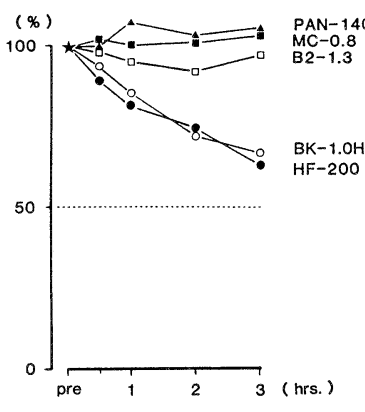

c: Retinol binding protein (MW:21000) n : 5

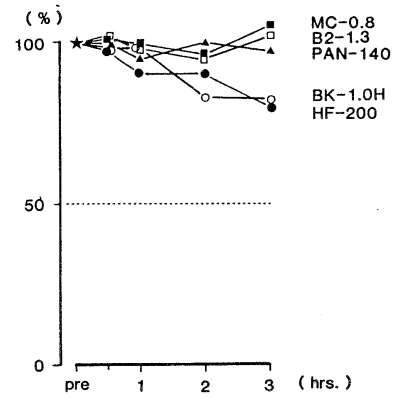

$d: \alpha 1-$ microgloburin $(\mathrm{MW}: 33000) \mathrm{n}: 5$

図 3 各種膜における溶質の経時的変化(2) 
HF-200 ( PMMA, B-1type, high flux ) $n: 5$

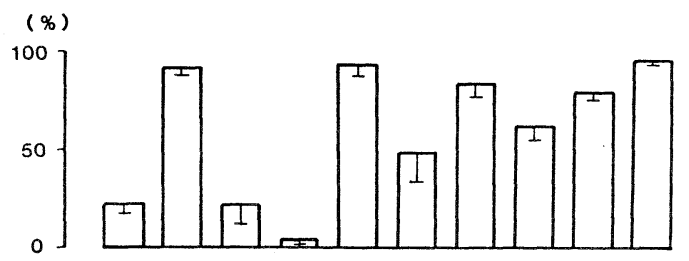

BK-1.OH（PMMA, B-1type，蛋白透過膜） $n: 5$

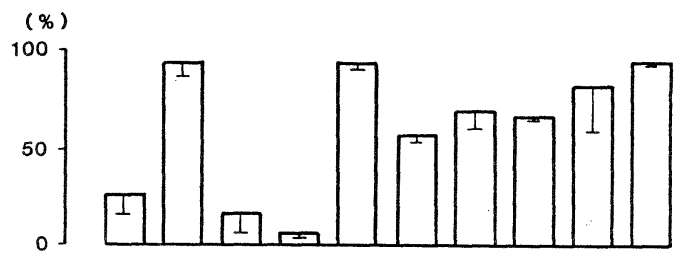

B2-1.3 ( PMMA, B-2type)

$n: 5$

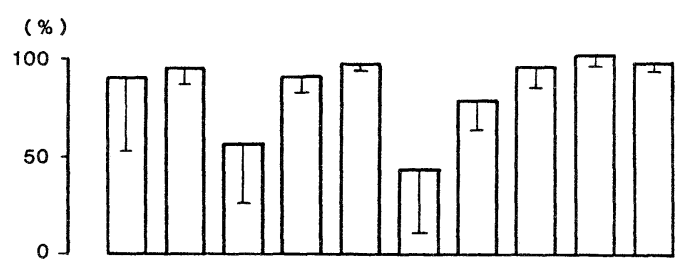

Gul. PTH PTH $\boldsymbol{\beta}_{2}$ Ribo. Lyso. Myo. RBP $\boldsymbol{\alpha}_{1}$ Transf. $\dot{C}$ INS $\dot{M G}$ $M G$

図４3 時間経過後の膜別溶質レベル (1)

hemofilter を用いてその治療法を試みてきだ).そして それらの治療経験の中で, ある種の hemofilter において 濾過されず濾液中には出現してこない溶質が，血中では 明らかに低下するという奇妙な現象が観察された。その 奇妙な現象を理解するために，我々は hemofilter 膜面で 溶質が吸着ないし付着されて除去される可能性を想定 し，その仮説を実証してきた ${ }^{3,5)}$.

今回再度この膜吸着実験を行うにあたり, PAN 膜 (PAN-140), cuprohan 膜 (MC-0.8), PMMA 膜 B1 系 (HF-200, BK-1.0 H) に加えて, B2 系 PMMA 膜 (B2-1.3) も含めて対象とした. PAN 膜, cuprohan 膜 においては前回同様の結果を示した ${ }^{3,5)}$. しかし PMMA 膜においては，B1 系と B2 系では同じ PMMA 膜であ りながら全く異なった結果を示した．特に $\beta_{2}-\mathrm{MG}$ に関 して言えば，B1 系の膜では $94 \%$ 以もの減少（吸着） をみたが, B2 系の膜では $9 \%$ と若干の減少をみたにすぎ なかった。この PMMA 膜 B1 系と B2 系との結果の違 いは，おそらくアイソタクテック PMMA (iso-PMMA) とシンジオタクテック PMMA (syn-PMMA) の混合比

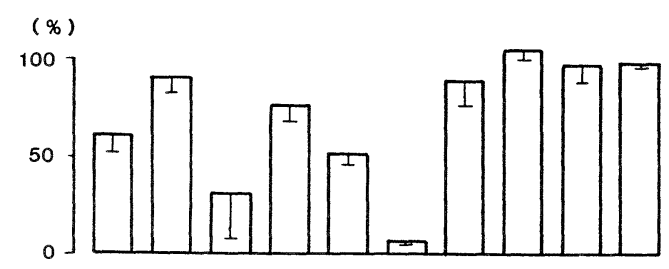

MC-0.8 ( Cuprophan ) $n: 5$

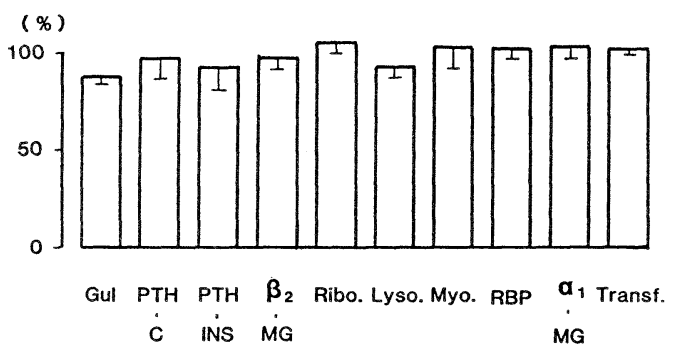

図 53 時間経過後の膜別溶質レベル(2)

率による膜の性質の違いによるものか, 含水率による開 孔（ポアサイズ）率の相違によるものか，またはその両 者の複雑な重合か，などによりコントロールされている と推測される ${ }^{6,7)}$. またさらにそれぞれの膜と溶質との間 には特異的な吸着（affinity）があり，溶質の構造や荷電 状態の差と, 膜表面の構造, 荷電状態の差との組み合わ せで，それぞれの affinity が異なることも重要な因子と して付け加えておかなくてはならないだろうう,

長期透析例に数多くみられる手根管症候群 (Carpal tunnel syndrome：CTS) を含めた透析性関節症 (dialysis-associated arthropathy) の頻度は，透析治療 期間の延長につれ増加傾向にある 関節症とアミロイドーシスとの関連が注目され，アミロ イド蛋白の前駆体として $\beta_{2}-\mathrm{MG}$ がすでに同定されてい る. そのため長期透析患者血中に著しく高濃度に貯溜し ている $\beta_{2}-\mathrm{MG}$ を除去することが不可決な治療 ${ }^{99}$ の 1 つ として今注目をあびている。

そのような中分子物質の除去において, 膜透過除去の 他に膜吸着除去も重要な要因として考えるべきと思われ る。

\section{文献}

1) Gejyo, F., Yamada, T., Odani, S., Nakagawa, Y., Arakawa, M., Kunitomo, T., Kataoka, H., Suzuki, M., Hirasawa, Y., Shirahama, T., Cohen, A. S. and Schmid, K. : A new form of amyloid protein 
associated with chronic hemodialysis was identified as $\beta_{2}$-microglobulin. Biochem Biophys Res Comm., 129 : 701-706, 1985.

2) Endoh, N., Fujimoto, M., Suzuki, M., and Hirasawa, Y. : Effective Removals of $\beta_{2}$-microglobulin by High Performance Membrane Dialyzers and Hemofilters. Artificial Organs, (投稿中).

3）遠藤信之, 保科 繁, 池田 裕, 中村藤夫, 古川 守, 中川一郎，阿部町子，浦野壽夫，鈴木正司，平沢由 平：血液濾過用フィルターでの血中溶質の吸着.人 工藏器, $12: 49-52,1983$.

4) 保科 繁, 遠藤信之, 池田 裕, 中村藤夫, 古川 守, 中川一郎, 阿部町子, 浦野壽夫, 鈴木正司, 平沢由 平：濾過型人工腎に関する研究.透析会誌, $11: 145$, 1978.
5）保科 繁, 遠藤信之, 池田 裕, 中村藤夫, 古川 守, 中川一郎, 阿部町子, 浦野壽夫, 鈴木正司, 平沢由 平：血液濾過用膜による物質吸着の可能性. 透析会 誌，16：139-143，1983.

6）梅香家鎮：血液浄化膜. 機能性膜の最先端技術.シー エムシー刊, 1982 .

7) 小野利彦, 松井 弘: 人工藏器特に人工腎臟の機能 性膜. 石油学会, 6：33-39，1983.

8）鈴木正司：透析性関節症. 臨床透析，2:204-205, 1986.

9）遠藤信之, 中川一郎, 古川 守, 中村藤夫, 保科 繁, 池田 裕, 阿部町子, 浦野壽夫, 鈴木正司, 平沢由 平：各種膜素材を用いた時の $\beta-\mathrm{MG} レ$ レルの動向 (血液透析・血液濾過), 腎と透析, 投稿中. 